\title{
Optimasi formula gel ekstrak kubis ungu (Brassica oleracea L. var. capitata f. rubra) menggunakan simplex lattice design dan pengujian aktivitas antioksidan secara in vitro
}

\author{
Rima Yulia Senja ${ }^{1}$, Akhmad Kharis Nugroho ${ }^{2}$, Erna Prawita Setyowati ${ }^{2}$ \\ ${ }^{1}$ Akademi Farmasi Muhammadiyah, Cirebon \\ Jl. Cideng Indah, Kertawinangun, Kedawung, Cirebon, Jawa Barat 45153 \\ ${ }^{2}$ Fakultas Farmasi, Universitas Gadjah Mada, Yogyakarta \\ Sekip Utara, Yogyakarta 55281
}

\begin{abstract}
ABSTRAK
Telah dilakukan penelitian optimasi formula gel ekstrak kubis ungu (Brassica oleracea L. var. capitata f.rubra) menggunakan metode Simplex Lattice Design dan pengujian aktivitas antioksidan formula gel dilakukan secara in vitro. Kubis ungu diekstraksi dengan soxhletasi menggunakan pelarut etanol 96\%. Penentuan formula optimum gel antioksidan ekstrak kubis ungu dengan metode Simplex Lattice Design menggunakan software Design-Expert ${ }^{\circledR}$ versi 7 (DX7) dan pengujian aktivitas antioksidan gel ekstrak kubis ungu dilakukan secara in vitro menggunakan metode spektrofotometri Ultra Violet. Stabilitas formula optimum gel dilihat melalui perbandingan sifat fisik pada awal pembuatan dan setelah penyimpanan 4 minggu menggunakan ANOVA, dengan taraf kepercayaan 95\%. Formula optimum gel ekstrak kubis ungu diperoleh pada proporsi Metolose 3,883\%, propilenglikol 13,5\%, Tween $801,117 \%$. Hasil evaluasi formula optimum gel ekstrak kubis ungu adalah luas permukaan sebar gel $38,99 \pm 3,27 \mathrm{~cm}^{2}$; viskositas gel 295,56 $\pm 1,93 \mathrm{dPa}$.s dan perubahan viskositas $3,89 \pm 0,96 \%$. Dari hasil analisis statistik uji-t satu sampel disimpulkan bahwa tidak ada perbedaan antara harga prediksi software dengan hasil observasi ( $\mathrm{p}>0,05)$. Hasil pengujian $\mathrm{IC}_{50}$ dari formula optimum gel ekstrak kubis ungu adalah $257,25 \pm 0,35 \mu \mathrm{g} / \mathrm{mL}$. Hasil pengujian stabilitas fisik formula optimum gel ekstrak kubis ungu mengalami penurunan $\mathrm{pH}$ pada penyimpanan setelah 4 minggu $(\mathrm{p}<0,05)$.
\end{abstract}

Kata kunci: kubis ungu, gel, Metolose, optimasi , antioksidan

\begin{abstract}
A study of optimization of red cabbage (Brassica oleracea.L. var. capitata f. rubra) gel extract formula has been performed by using Simplex Lattice Design (SLD) method and antioxidant activity of the formula gel was also evaluated by using in vitro method.The red cabbage was extracted by soxhletation by using ethanol $96 \%$ followed by optimization of red cabbage extract in antioxidant gel preparation used SLD method by Design-Expert® software version 7 (DX7) and determination of its $\mathrm{IC}_{50}$ used UV-Spectrophotometry. The stability of optimum gel formula is seen through comparison of physycal properties at the beginning and after four weeks storage used ANOVA, with a $95 \%$ significant level. Optimum gel formula of red cabbage extract obtained in the proportion of Metolose 3,883\%, propilen glikol 13.5\%, Tween $801.117 \%$. The evaluation results of optimum gel formula of red cabbage extract is the surface area of gel dispersive of $38.99 \pm 3.27 \mathrm{~cm}^{2}$; viscosity gel dPa.s of $295.56 \pm 1.93$ and viscosity change $3.89 \pm 0.96 \%$. From the results of statistical analysis of one t-test sample was concluded that there was no difference between the prediction price of software with the observation result (p> $0.05)$.
\end{abstract}

Penulis korespondesi:

Rima Yulia Senja

Akademi Farmasi Muhammadiyah, Cirebon

Jl. Cideng Indah, Kertawinangun, Kedawung, Cirebon, Jawa Barat 45153

Email: rimayuliasenja@gmail.com 
The $\mathrm{IC}_{50}$ test result of the optimum formula of red cabbage extract gel was $257.25 \pm 0.35 \mu \mathrm{g} / \mathrm{mL}$. The testing result of the physical stability of the optimum formula of red cabbage extract gel suffered a $\mathrm{pH}$ decrease after 4 weeks of storage $(\mathrm{p}<0.05)$.

Keywords: red cabagge, gel, Metolose, optimization, antioxidant

\section{PENDAHULUAN}

Beberapa studi epidemiologi menunjukkan bahwa peningkatan konsumsi antioksidan alami yang terdapat dalam buah dan sayuran mempunyai manfaat yang besar terhadap kesehatan, yaitu dapat mengurangi resiko terjadinya penyakit jantung koroner. Antioksidan memiliki kemampuan mencegah terjadinya penuaan dini serta dapat mengurangi tingkat keparahan/kerusakan kulit akibat radiasi UV. Antioksidan mampu merangsang produksi kolagen yang merupakan bagian penting dari struktur dan proses peremajaan kulit (Ghiselli dkk., 1998). Salah satu kandungan di dalam kubis ungu (Brassica oleracea L. var. capitata f. rubra) adalah antosianin yang berada dalam bentuk glikosida yang terikat molekul gula (cyanidin-3-diglucoside-5-glucoside). Senyawa ini mempunyai efek penting bagi tubuh, seperti perlindungan terhadap penyakit kardiovaskuler, diabetes mellitus, antinflamasi, antikanker dan antioksidan (Mazza dan Miniati, 1993; Giusti dan Wrolstad, 2001). Antosianin pada kubis ungu, ditemukan memiliki kekuatan antioksidan terkuat 150 kali flavonoid (Neelufar dkk., 2012).

Berdasarkan penelitian pendahuluan yang dilakukan sebelumnya, ekstrak kubis ungu dengan metode soxhletasi dari bahan segar menggunakan pelarut etanol $96 \%$ dan dilanjutkan dengan proses oven pada suhu $100^{\circ} \mathrm{C}$ selama 1 jam, memberikan aktivitas antioksidan tertinggi dibandingkan beberapa metode ekstraksi yang lain yaitu dengan nilai $\mathrm{IC}_{50} 168,78 \pm 5,15 \mu \mathrm{g} / \mathrm{mL}$ dan rendemen ekstrak yang diperoleh yaitu 2,48 gram/100 gram kubis ungu segar (Senja dkk., 2014).

Bahan alam dapat digunakan sebagai alternatif dalam pembuatan produk antioksidan topikal. Pada penelitian ini, akan dibuat formulasi gel dari ekstrak kubis ungu dan uji aktivitas antioksidan sediaan. Gel memiliki keuntungan lebih mudah dicuci dengan air dan tidak meninggalkan rasa lengket pada kulit. Kualitas fisik sediaan gel dipengaruhi oleh komposisi bahan yang digunakan. Komponen basis gel yang digunakan dalam penelitian ini yaitu Metolose, propilenglikol dan Tween 80. Metolose dapat menghasilkan gel yang netral, jernih, tidak berwarna, stabil pada $\mathrm{pH}$ 3-11. Propilenglikol berperan sebagai humektan, sedangkan Tween 80 digunakan sebagai surfaktan untuk meningkatkan kestabilan ekstrak kubis ungu dalam formula. Besarnya proporsi komponen-komponen tersebut perlu dioptimasi agar dihasilkan sediaan gel dengan sifat-sifat fisik yang diharapkan. Metode Simplex Lattice Design dapat digunakan untuk optimasi formula pada berbagai jumlah komposisi bahan yang berbeda (Bolton, 1997).

Penelitian ini bertujuan untuk mendapatkan formula optimum gel ekstrak kubis ungu menggunakan tiga komponen dalam basis yaitu Metolose, propilenglikol dan Tween 80 berdasarkan metode Simplex Lattice Design menggunakan software Design Expert ${ }^{\circledR}$ versi 7 pada program mixture design berdasarkan hasil uji fisik serta stabilitas formula optimum selama 4 minggu penyimpanan serta aktivitas antioksidan sediaan.

\section{METODOLOGI PENELITIAN}

\section{Alat dan Bahan}

Alat-alat yang digunakan dalam penelitian ini adalah soxhlet, oven, neraca elektrik (Mettler toledo, Japan) dengan kapasitas 0,021-210 g, spektrofotometer UV-Vis (Model U-2900, Japan), mikropipet (Gilson pipetmen, Germany) 20-100 $\mu \mathrm{L}, 100-1000 \mu \mathrm{L}$, mikser, viscotester Rion-Japan VT 04, $\mathrm{pH}$ meter, dan alat uji daya sebar. Bahan-bahan yang digunakan adalah kubis ungu (waktu panen 3 bulan dan berwarna ungu tua) yang berasal dari perkebunan di Lembang, radikal DPPH (2,2 difenil-1pikrilhidrazil), rutin, etanol (kualitas p.a. E. Merck, Germany), Metolose (60SH), propilen glikol, Tween 80, metil paraben, dan propil paraben (kualitas farmasi).

\section{Jalannya Penelitian Ekstraksi kubis ungu}

Proses ekstraksi kubis ungu yang dilakukan pada penelitian ini merupakan hasil penelitian pendahuluan yang dilakukan sebelumnya, yaitu optimasi metode dan pelarut dalam ekstraksi kubis ungu yang menghasilkan aktivitas antioksidan tertinggi (Senja dkk., 2014). Sejumlah kubis ungu segar yang 
telah dihaluskan dengan blender, dimasukkan ke dalam alat soxhlet, kemudian ditambahkan etanol 96\% sebagai pelarut dengan perbandingan 1:10 sampai seluruh bahan terendam. Proses ekstraksi dilakukan sampai diperoleh larutan penyari yang jernih. Ekstrak yang diperoleh dipekatkan menggunakan vaccum rotary evaporator dengan suhu $70^{\circ} \mathrm{C}$ hingga diperoleh ekstrak kental. Ekstrak dikeringkan dengan oven pada suhu $100^{\circ} \mathrm{C}$ selama 1 jam (Liliana dkk., 2010; Senja dkk., 2014).

\section{Optimasi formula gel ekstrak kubis ungu}

Faktor yang akan dioptimasi adalah Metolose, propilenglikol dan Tween 80 . Formula 100 gram gel terdapat pada Tabel I.

Tabel I. Formula gel ekstrak kubis ungu

\begin{tabular}{lc}
\hline \multicolumn{1}{c}{ Formula } & Jumlah (gram) \\
\hline $\begin{array}{l}\text { Ekstrak kubis ungu } \\
\text { Metolose 60SH }\end{array}$ & 0,3 \\
$\begin{array}{l}\text { Propilen glikol } \\
\text { Tween 80 }\end{array}$ & 18,5 \\
Etanol 96\% & \\
Metil paraben & $10 \mathrm{~mL}$ \\
Propil paraben & 0,1 \\
Aqua Ad & 0,05 \\
\hline
\end{tabular}

Tabel II. Run formula gel ekstrak kubis ungu berdasarkan Simplex Lattice Design dengan menggunakan Software Design-Expert ${ }^{\circledR}$ versi 7 (DX7)

\begin{tabular}{ccccccccc}
\hline Run & $\begin{array}{c}\text { Ekstrak } \\
\text { Kubis } \\
\text { Ungu } \\
\text { (gram) }\end{array}$ & $\begin{array}{c}\text { Metolose } \\
\text { (gram) }\end{array}$ & $\begin{array}{c}\text { Propilen } \\
\text { glikol } \\
\text { (gram) }\end{array}$ & $\begin{array}{c}\text { Tween } \\
\mathbf{8 0} \\
\text { (gram) }\end{array}$ & $\begin{array}{c}\text { Metil } \\
\text { Paraben } \\
\text { (gram) }\end{array}$ & $\begin{array}{c}\text { Propil } \\
\text { Paraben } \\
\text { (gram) }\end{array}$ & $\begin{array}{c}\text { Etanol } \\
\mathbf{9 6 \%} \\
(\mathbf{m L})\end{array}$ & $\begin{array}{c}\text { Aqua } \\
\text { (mL) }\end{array}$ \\
\hline & & & & & & & & \\
I & 0,3 & 3,75 & 13,50 & 1,25 & 0,1 & 0,05 & 10 & 71,05 \\
II & 0,3 & 4,00 & 13,75 & 0,75 & 0,1 & 0,05 & 10 & 71,05 \\
III & 0,3 & 3,25 & 13,75 & 1,50 & 0,1 & 0,05 & 10 & 71,05 \\
IV & 0,3 & 3,00 & 13,50 & 2,00 & 0,1 & 0,05 & 10 & 71,05 \\
V & 0,3 & 4,50 & 13,50 & 0,50 & 0,1 & 0,05 & 10 & 71,05 \\
VI & 0,3 & 3,75 & 14,25 & 0,50 & 0,1 & 0,05 & 10 & 71,05 \\
VII & 0,3 & 3,00 & 15,00 & 0,50 & 0,1 & 0,05 & 10 & 71,05 \\
VIII & 0,3 & 3,75 & 14,25 & 0,50 & 0,1 & 0,05 & 10 & 71,05 \\
IX & 0,3 & 3,00 & 13,50 & 2,00 & 0,1 & 0,05 & 10 & 71,05 \\
X & 0,3 & 3,00 & 14,25 & 1,25 & 0,1 & 0,05 & 10 & 71,05 \\
XI & 0,3 & 3,25 & 14,50 & 0,75 & 0,1 & 0,05 & 10 & 71,05 \\
XII & 0,3 & 4,50 & 13,50 & 0,50 & 0,1 & 0,05 & 10 & 71,05 \\
XIII & 0,3 & 3,50 & 14,00 & 1,00 & 0,1 & 0,05 & 10 & 71,05 \\
XIV & 0,3 & 3,00 & 15,00 & 0,50 & 0,1 & 0,05 & 10 & 71,05 \\
\hline
\end{tabular}

Tahapan pembuatan gel ekstrak kubis ungu yaitu mula-mula dilakukan pembuatan basis gel. Air panas (20 kali jumlah Metolose) dimasukkan dalam beaker glass, kemudian Metolose ditaburkan di atas air panas tersebut, dibiarkan sampai mengembang kurang lebih 15 menit, dan diaduk dengan homogenizer pada kecepatan rendah $(160 \mathrm{rpm})$ sampai membentuk gel. Metil paraben dan propil paraben masing-masing dilarutkan dalam sedikit etanol kemudian dicampur menjadi satu dan diaduk sampai homogen (Larutan 1). Basis gel ditambahkan Tween 80, diaduk dengan homogenizer kecepatan rendah (160 rpm), ditambahkan propilen glikol dan Larutan 1 dan diaduk sampai homogen. Campuran dibiarkan selama 24 jam di lemari pendingin pada suhu $10^{\circ} \mathrm{C}$. Ekstrak kubis ungu dilarutkan dalam etanol sampai larut (Larutan 2). Basis gel kemudian ditambahkan larutan 2, kemudian diaduk dengan homogenizer pada kecepatan rendah sampai homogen. Untuk melihat pengaruh ketiga komponen terhadap respon (viskositas, perubahan viskositas dan luas permukaan daya sebar) dibuat 14 macam run formula berdasarkan software Design-Expert ${ }^{\circledR}$ versi 7 (DX7). Rancangan proporsi komponen tiap formula tersaji dalam Tabel II. 


\section{Uji sifat fisik dan stabilitas fisik gel}

\section{Uji organoleptik}

Uji organoleptik meliputi pengamatan terhadap bentuk, warna dan bau dari sediaan yang telah dibuat (Djajadisastra dan Dessy, 2009)

\section{Uji homogenitas}

Sediaan gel dioleskan pada kaca transparan dimana sediaan diambil dari 3 bagian yaitu atas, tengah dan bawah. Homogenitas ditunjukkan dengan tidak adanya butiran kasar (Djajadisastra dan Dessy, 2009).

\section{Uji daya sebar dan perhitungan luas permukaan sebar gel}

Uji daya sebar dilakukan untuk menjamin pemerataan gel saat diaplikasikan pada kulit. Sediaan gel ditimbang sebanyak 1,0 g kemudian diletakkan ditengah kaca bulat berskala. Di atas gel diletakkan kaca bulat transparan dan pemberat sehingga berat kaca bulat dan pemberat $150 \mathrm{~g}$, didiamkan 1 menit, kemudian dicatat diameter penyebarannya dan luas permukaan sebarnya (Garg dkk., 2002).

\section{Uji pH}

Sediaan gel diukur $\mathrm{pH}$ nya dengan menggunakan $\mathrm{pH}$ meter yang telah dikalibrasi menggunakan larutan dapar standar $\mathrm{pH} 4$ dan $\mathrm{pH}$ 7. Sediaan gel harus memenuhi kriteria $\mathrm{pH}$ kulit yaitu dalam interval 4,5 -6,5 (Djajadisastra dan Dessy, 2009).

\section{Uji viskositas}

Pengujian Viskositas menggunakan Viscotester Rion seri VT-04. Uji stabilitas fisik dengan metode cycling test. Gel disimpan pada suhu $4^{\circ} \mathrm{C}$ selama 24 jam lalu dikeluarkan dan ditempatkan pada suhu $40^{\circ} \mathrm{C}$ selama 24 jam. Perlakuan ini adalah satu siklus. Percobaan diulang sebanyak 6 siklus. Kondisi fisik sediaan dibandingkan dengan kondisi fisik sebelumnya selama percobaan (Djajadisastra dan Dessy, 2009).

\section{Penentuan aktivitas antioksidan formula optimum gel ekstrak kubis ungu dengan metode peredaman radikal bebas DPPH (Azlim dkk., 2010)}

\section{Penyiapan sampel}

Sampel gel sebanyak $1.005 \mathrm{mg}$ diekstraksi dengan $20 \mathrm{~mL}$ etanol $96 \%$ dalam corong pisah selama 5 menit. Filtrat dimasukkan ke labu ukur dan ditambahkan etanol sampai 25,0 mL. Hasil ekstraksi kemudian disonifikasi, bila perlu dilakukan proses penyaringan sampai diperoleh filtrat jernih.

\section{Uji peredaman radikal bebas DPPH (uji kuantitatif)}

Larutan induk (LI) sampel dibuat dengan konsentrasi $1,0005 \mathrm{mg} / \mathrm{mL}$ dalam etanol. Sebanyak 0,25 ; 1,$5 ; 2,5 ; 3 ; 5$ mL LI sampel dimasukkan ke dalam labu ukur 10,0 mL. Ke dalam labu ukur ditambahkan etanol sampai batas kalibrasi hingga diperoleh konsentrasi $25 \mu \mathrm{g} / \mathrm{mL} ; 150 \mu \mathrm{g} / \mathrm{mL} ; 250 \mu \mathrm{g} / \mathrm{mL} ; 300 \mu \mathrm{g} / \mathrm{mL}$ dan $500 \mu \mathrm{g} / \mathrm{mL}$. Larutan sampel dipipet sebanyak $1 \mathrm{~mL}$ dimasukkan ke dalam labu ukur 5,0 $\mathrm{mL}$, ditambahkan 1,0 mL DPPH dan etanol sampai tanda batas. Larutan tersebut diinkubasi pada suhu kamar selama 30 menit. Absorbansi sampel diukur dengan spektrofotometri UV-Vis pada panjang gelombang $517 \mathrm{~nm}$.

Aktivitas antioksidan sampel ditentukan oleh besarnya hambatan serapan radikal DPPH melalui perhitungan persentase inhibisi serapan DPPH dengan menggunakan rumus:

$\%$ inhibisi $=\frac{\text { Absorbansi kontrol-Absorbansi sampel }}{\text { Absorbansi kontrol }} \times 100 \%$

Data absorbansi yang diperoleh dibuat persamaan regresi linear yang menyatakan hubungan antara konsentrasi bahan uji $(\mathrm{x})$ dengan aktivitas penangkap radikal rata-rata (y) dari suatu seri replikasi pengukuran sehingga diperoleh harga $\mathrm{IC}_{50}$. 


\section{HASIL DAN PEMBAHASAN \\ Hasil Ekstraksi Kubis ungu}

Metode yang digunakan untuk proses ekstraksi sesuai dengan penelitian pendahuluan dari penelitian ini yaitu metode soxhletasi dari bahan segar menggunakan pelarut etanol $96 \%$ dengan proses oven pada suhu $100^{\circ} \mathrm{C}$ selama $1 \mathrm{jam}$. Metode ekstraksi tersebut memberikan aktivitas antioksidan ekstrak kubis ungu tertinggi dibandingkan beberapa metode ekstraksi yang lain yaitu dengan nilai $\mathrm{IC}_{50} 168,78 \pm$ $5,15 \mu \mathrm{g} / \mathrm{mL}$ dan rendemen ekstrak yang diperoleh yaitu 2,48 gram/100 gram kubis ungu segar (Senja dkk., 2014).

\section{Formulasi Gel \\ Hasil Uji Sifat Fisik Gel Ekstrak Kubis Ungu}

Komposisi formula gel yang digunakan dalam optimasi ini adalah : ekstrak kubis ungu 0,3\%, Metolose $60 \mathrm{SH} 3-4,5 \%$, Tween $800,5-2 \%$, metil paraben $0,1 \%$, propil paraben $0,05 \%$ dan aquades sampai $100 \%$. Uji fisik sediaan gel dengan basis metolose dilakukan pada hari ke-2 atau pada penyimpanan 48 jam karena pada hari ke-2 komponen penyusun dalam sistem gel telah tersusun dengan baik (Garg, 2002). Sifat fisik sediaan gel yang akan diuji diantaranya yaitu organoleptis, daya sebar, $\mathrm{pH}$ dan viskositas. Hasil uji daya sebar, viskositas dan perubahan viskositas dari formula gel terdapat pada Tabel III.

Hasil pengamatan organoleptis formula gel memberikan karakter fisik yang sama yaitu bentuk gel, warna merah muda, bau khas kubis. Pada Tabel III, sediaan gel ekstrak kubis ungu mempunyai luas permukaan sebar antara $31,41 \mathrm{~cm}^{2}$ sampai $57,44 \mathrm{~cm}^{2}$. Hasil penelitian menunjukkan peningkatan konsentrasi metolose menyebabkan penurunan luas permukaan sebar. Hal ini didasarkan karena metolose mempunyai daya mengembang yang tidak terbatas artinya pada penambahan air yang cukup besar akan berubah menjadi bentuk solutio (Voigt, 1984). Pada uji viskositas dari ke empat belas run formula, run V dan run XII memiliki viskositas yang tinggi dikarenakan persentase metolose paling besar. Peningkatan jumlah gelling agent dapat memperkuat matriks gel sehingga menyebabkan kenaikan viskositas (Lieberman, 1998). Persentase perubahan viskositas gel dihitung berdasarkan perbandingan nilai viskositas pada minggu ke-4 terhadap viskositas pada minggu ke-1. Run VII memiliki persentase perubahan viskositas terkecil dibandingkan dengan formula lain, semakin kecil perubahan viskositas makan sediaan lebih stabil dalam penyimpanan yang lama.

Hasil pemeriksaan $\mathrm{pH}$ pada formula gel ekstrak kubis ungu menunjukkan adanya penurunan $\mathrm{pH}$ sediaan setelah penyimpanan 4 minggu pada suhu kamar. Penurunan $\mathrm{pH}$ formula gel ekstrak kubis ungu masih memenuhi kriteria pH kulit yaitu dalam interval 4,5 - 6,5 (Djajadisastra dan Dessy., 2009). Penurunan $\mathrm{pH}$ sediaan selama penyimpanan merupakan indikasi ketidakstabilan formula.

\section{Luas permukaan sebar}

Berdasarkan persamaan simplex lattice design untuk respon luas permukaan sebar gel (Tabel IV) dapat dilihat pengaruh terbesar pada peningkatan luas permukaan sebar gel yaitu pada komponen Tween 80 sebesar $+55,79$. Interaksi dua komponen dapat menurunkan luas permukaan sebar gel, yaitu pada interaksi antara propilen glikol-Tween 80 sebesar -44,02; Metolose-propilen glikol sebesar -5,95; Metolose-Tween 80 sebesar -5,68 sedangkan interaksi ketiga komponen (Metolose-propilen glikolTween 80) memberikan pengaruh positif atau meningkatkan luas permukaan sebar gel dengan nilai koefisien sebesar $+327,94$. Berdasarkan persamaan (special cubic model) diperoleh diagram contour plot untuk respon luas permukaan sebar gel seperti pada Gambar 1. Peningkatan konsentrasi Tween 80 dapat meningkatkan luas permukaan sebar gel. Hasil ANOVA untuk pengukuran aktual dan prediksi model menurut software design-expert ${ }^{\circledR}$ versi 7 (DX7) menunjukkan tidak ada perbedaan bermakna untuk respon luas permukaan sebar gel dimana lack of fit yang dihasilkan sebesar 0,3266. 
Tabel III. Hasil uji fisik dan stabilitas formula ekstrak kubis ungu

\begin{tabular}{ccccc}
\hline Run & $\begin{array}{c}\text { Luas permukaan } \\
\text { sebar }\left(\mathbf{c m}^{\mathbf{2}}\right)\end{array}$ & $\begin{array}{c}\text { Viskositas } \\
\text { Minggu ke-1 } \\
(\mathbf{d P a} . \mathbf{S})\end{array}$ & $\begin{array}{c}\text { Viskositas } \\
\text { Minggu ke-4 } \\
(\mathbf{d P a} . \mathbf{S})\end{array}$ & $\begin{array}{c}\text { Persentase } \\
\text { Perubahan } \\
\text { viskositas } \\
(\boldsymbol{\%})\end{array}$ \\
\hline I & $44,65 \pm 0,17$ & $291,67 \pm 0,88$ & $283,89 \pm 1,58$ & $2,67 \pm 0,65$ \\
II & $39,95 \pm 1,41$ & $433,75 \pm 3,03$ & $406,67 \pm 1,20$ & $6,24 \pm 0,49$ \\
III & $47,26 \pm 1,15$ & $235,42 \pm 2,60$ & $221,33 \pm 0,67$ & $5,99 \pm 1,15$ \\
IV & $57,44 \pm 4,16$ & $164,00 \pm 0,15$ & $155,10 \pm 1,51$ & $5,43 \pm 0,83$ \\
V & $35,86 \pm 0,55$ & $512,50 \pm 2,63$ & $490,00 \pm 1,00$ & $4,39 \pm 0,42$ \\
VI & $31,41 \pm 0,43$ & $344,43 \pm 1,20$ & $334,43 \pm 2,14$ & $2,90 \pm 0,88$ \\
VII & $32,15 \pm 0,50$ & $157,53 \pm 0,61$ & $155,00 \pm 2,60$ & $1,61 \pm 2,01$ \\
VIII & $33,08 \pm 0,82$ & $335,00 \pm 0,25$ & $327,00 \pm 1,53$ & $2,39 \pm 0,44$ \\
IX & $54,63 \pm 1,91$ & $164,33 \pm 0,97$ & $156,78 \pm 1,26$ & $4,59 \pm 0,32$ \\
X & $33,26 \pm 1,15$ & $138,25 \pm 1,52$ & $133,33 \pm 3,34$ & $3,56 \pm 2,56$ \\
XI & $39,60 \pm 0,90$ & $146,10 \pm 1,43$ & $140,45 \pm 0,51$ & $3,87 \pm 0,65$ \\
XII & $33,62 \pm 2,48$ & $510,33 \pm 0,24$ & $487,89 \pm 3,02$ & $4,40 \pm 0,61$ \\
XIII & $47,68 \pm 2,46$ & $295,42 \pm 3,82$ & $280,55 \pm 1,68$ & $5,03 \pm 1,11$ \\
XIV & $33,60 \pm 1,04$ & $154,47 \pm 0,60$ & $150,07 \pm 0,68$ & $2,85 \pm 0,46$ \\
\hline
\end{tabular}

\section{Optimasi formula gel ekstrak kubis ungu}

Optimasi formula gel ekstrak kubis ungu dilakukan dengan memasukkan data sifat-sifat fisik dan stabilitas keseluruhan formula sebagai respon ke dalam software design-expert ${ }^{\circledR}$ versi 7 (DX7). Data sifat fisik gel pada Tabel III dianalisa dengan menggunakan software design-expert ${ }^{\circledR}$ versi 7 untuk mendapatkan persamaan simpleks lattice design seperti tercantum pada Tabel IV.

\section{Viskositas}

Berdasarkan persamaan simplex lattice design untuk respon viskositas (Tabel IV) dapat dilihat dominasi Metolose dalam menentukan viskositas gel tampak jelas dibandingkan efek propilen glikol dan Tween 80. Semakin besar konsentrasi Metolose, maka viskositas gel akan meningkat. Interaksi Metolose-propilen glikol-Tween 80 memberikan efek positif atau meningkatkan viskositas sebesar $+1106,40$ sedangkan interaksi Metolose-Tween 80 sebesar -118,61 dan propilen glikol-Tween 80 sebesar -91,46 memberikan efek menurunkan viskositas. Berdasarkan persamaan (cubic model) diperoleh diagram contour plot untuk respon viskositas seperti pada Gambar 2.

Tabel IV. Persamaan Simpleks Lattice Design formula gel ekstrak kubis ungu

\begin{tabular}{ll}
\hline \multicolumn{1}{c}{ Respon (Y) } & \multicolumn{1}{c}{ Persamaan Simpleks Lattice Design } \\
\hline \multirow{2}{*}{ Luas permukaan sebar $\left(\mathrm{cm}^{2}\right)$} & $\mathrm{Y}=+34,53 \mathrm{~A}+33,24 \mathrm{~B}+55,79 \mathrm{C}-5,95 \mathrm{AB}-5,68 \mathrm{AC}-$ \\
& $44,02 \mathrm{BC}+327,94 \mathrm{ABC}$ \\
Viskositas (dPa.S) & $\mathrm{Y}=511,07 \mathrm{~A}+155,66 \mathrm{~B}+163,82 \mathrm{C}+22,65 \mathrm{AB}$ \\
& $-188,61 \mathrm{AC}-91,46 \mathrm{BC}+1106,40 \mathrm{ABC}+1325,29 \mathrm{AB}(\mathrm{A}-\mathrm{B})$ \\
& $-522,88 \mathrm{AC}(\mathrm{A}-\mathrm{C})$ \\
Perubahan viskositas $(\%)$ & $\mathrm{Y}=+4,58 \mathrm{~A}+2,14 \mathrm{~B}+5,08 \mathrm{C}-2,49 \mathrm{AB}-6,59 \mathrm{AC}-$ \\
& $0,37 \mathrm{BC}+84,50 \mathrm{ABC}$ \\
\hline
\end{tabular}

\section{Keterangan:}
A : Proporsi komponen Metolose (bagian)
B : Proporsi komponen Propilenglikol (bagian)
C : Proporsi komponen Tween 80 (bagian) 


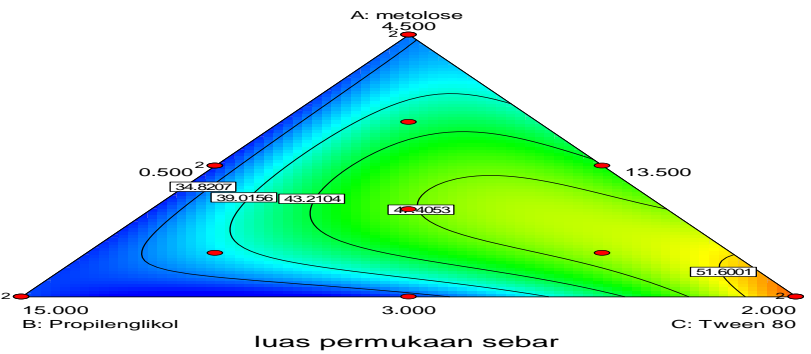

Gambar 1. Diagram Contour plot luas permukaan sebar gel ekstrak kubis ungu

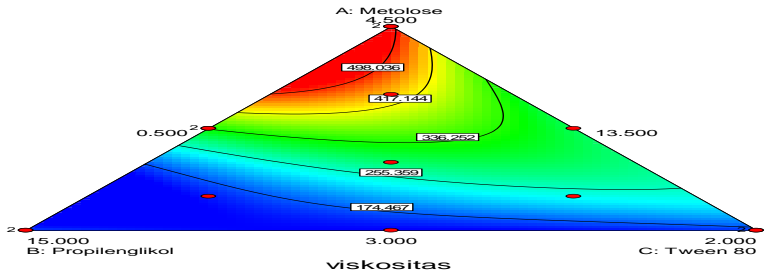

Gambar 2. Diagram Contour plot viskositas gel ekstrak kubis ungu

Hasil ANOVA untuk pengukuran aktual dan prediksi model menurut software design-expert ${ }^{\circledR}$ versi 7 (DX7) untuk respon viskositas tidak ada perbedaan bermakna dimana lack of fit yang dihasilkan 0,0533.

\section{Perubahan viskositas}

Berdasarkan persamaan simplex lattice design untuk respon perubahan viskositas gel (Tabel IV) dapat dilihat bahwa masing-masing komponen dapat meningkatkan perubahan viskositas gel. Tween 80 memberikan efek perubahan viskositas paling tinggi yaitu $+5,05$ sedangkan propilen glikol memberikan efek perubahan viskositas terkecil yaitu $+2,14$. Berdasarkan nilai efek tersebut maka propilen glikol merupakan faktor yang dominan dalam menentukan perubahan viskositas gel. Interaksi ketiga komponen (Metolose-propilen glikol-Tween 80) meningkatkan perubahan viskositas gel dengan nilai koefisien $+84,50$. Berdasarkan persamaan (special cubic model) diperoleh diagram contour plot untuk respon perubahan viskositas seperti pada Gambar 3.

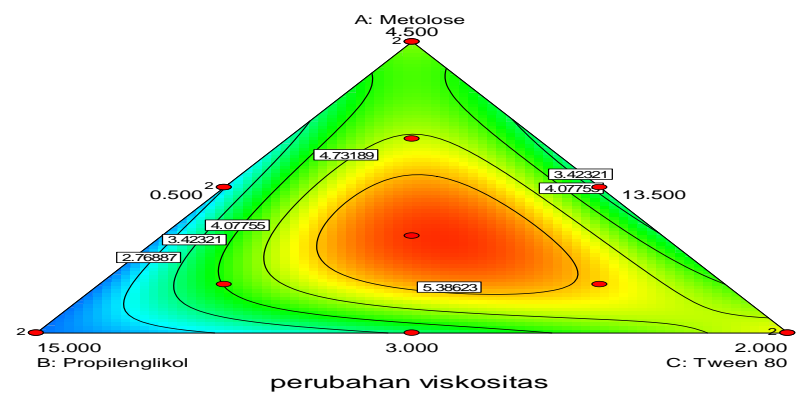

\section{Gambar 3. Diagram Contour plot perubahan viskositas gel ekstrak kubis ungu}

Viskositas gel dipengaruhi oleh gelling agent. Dalam sistem gel, gelling agent bertanggung jawab terhadap terbentuknya matriks gel. Selama penyimpanan, matriks gel dapat mengalami kerusakan yang menyebabkan perubahan viskositas gel. Counter plot perubahan viskositas menggambarkan semakin banyak propilen glikol maka perubahan viskositas akan semakin kecil. Perubahan viskositas semakin kecil diartikan bahwa stabilitas fisik gel semakin baik. Suatu gel dikatakan stabil apabila tidak ada perubahan dalam sifat alirnya. Propilen glikol mempunyai karakteristik yang spesifik pada sistem gel, dimana propilenglikol mempunyai efek memperkecil daya sebar walaupun viskositas juga kecil. Hal tersebut mungkin disebabkan sifat viskoelastik dari propilenglikol. Hasil ANOVA untuk pengukuran aktual dan prediksi model menurut software design-expert ${ }^{\circledR}$ versi 7 (DX7) untuk respon perubahan viskositas tidak ada perbedaan bermakna dimana lack of fit yang dihasilkan 0,0962. 


\section{Penentuan formula optimum gel ekstrak kubis ungu}

Pada penelitian ini digunakan pendekatan numerik untuk menentukan formula optimum. Sifat fisik dan stabilitas yang dimasukkan sebagai respon adalah luas permukaan sebar, viskositas dan persentase perubahan viskositas. Parameter yang digunakan dalam penentuan formula optimum gel antioksidan ekstrak kubis ungu yaitu luas permukaan sebar $\left(19,625-38,465 \mathrm{~cm}^{2}\right)$, viskositas $200-300 \mathrm{dPa} . \mathrm{S}$ dan perubahan viskositas 1,61-6,24\%. Diagram superimposed contour plot untuk menentukan daerah optimum dapat dilihat pada Gambar 4.

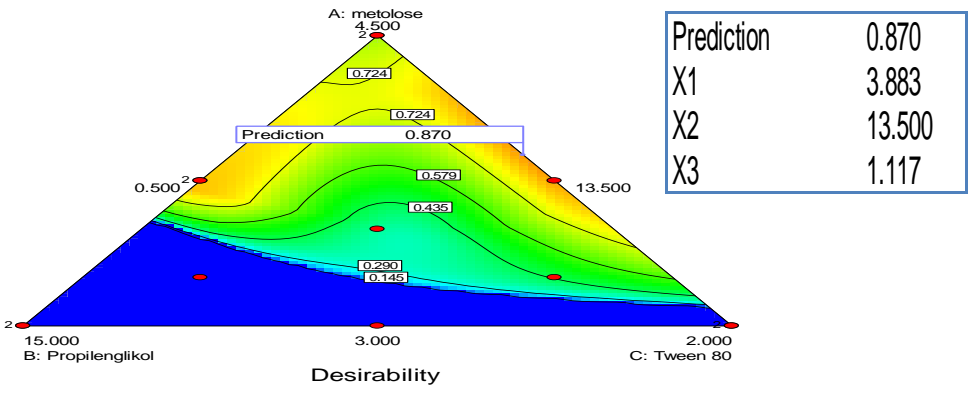

Gambar 4. Diagram superimposed contour plot respon luas permukaan sebar, viskositas dan persentase perubahan viskositas gel ekstrak kubis ungu

Contour plot ketiga respon di atas yaitu luas permukaan sebar, viskositas dan perubahan viskositas gel menunjukkan kurva-kurva yang melengkung. Hal tersebut menggambarkan bahwa dalam formula gel antioksidan tersebut terjadi interaksi antara Metolose, propilen glikol dan Tween 80. Interaksi ini memang diharapkan terjadi untuk mendapatkan sifat fisik optimum yang dikehendaki. Penentuan daerah optimum gel antioksidan ekstrak kubis ungu menggunakan software Design-Expert ${ }^{\circledR}$ versi 7 (DX7). Pada diagram superimposed contour plot di atas terlihat bahwa formula yang terpilih sebagai formula optimum menurut software adalah formula yang mengandung Metolose 3,883\%, propilen glikol 13,5\% dan Tween $801,117 \%$. Formula optimum gel ekstrak kubis ungu yang dihasilkan dapat dilihat pada Gambar 5.

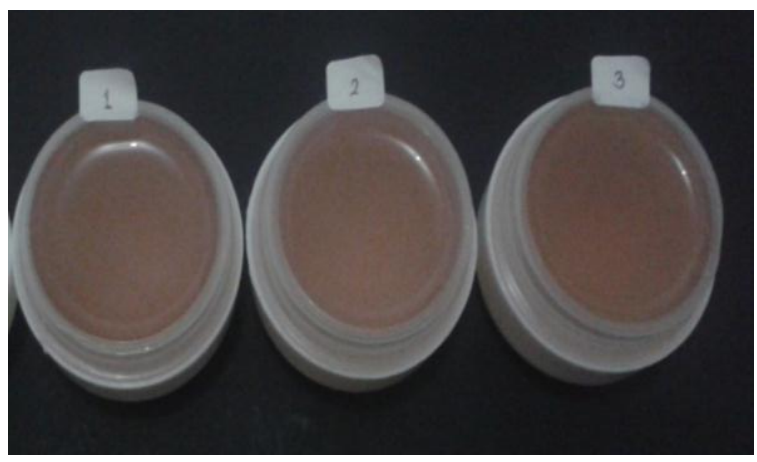

Gambar 5. Formula optimum gel ekstrak kubis ungu

$$
\begin{aligned}
& \text { Keterangan : } \text { 1. Formula optimum replikasi } 1 \\
& \text { 2. Formula optimum replikasi } 2 \\
& \text { 3. Formula optimum replikasi } 3
\end{aligned}
$$

Prediksi respon yang diperoleh dari analisis menggunakan software Design Expert ${ }^{\circledR}$ versi 7 selanjutnya dibandingkan dengan respon yang diperoleh pada percobaan. Uji-t satu sampel digunakan untuk menguji perbedaan rata-rata suatu sampel dengan nilai hipotesis. Hasil uji-t satu sampel respon prediksi dan respon percobaan formula optimum disajikan pada Tabel V.

Respon luas permukaan sebar gel, viskositas, perubahan viskositas menunjukkan hasil yang tidak berbeda bermakna antara prediksi software Design Expert ${ }^{\circledR}$ versi 7 (DX7) dengan hasil percobaan. Hal ini ditunjukkan oleh nilai $p$ yang lebih besar atau sama dengan 0,05 sehingga hasil percobaan yang dihasilkan adalah valid. 
Tabel V. Hasil uji-t satu sampel formula prediksi software DX7 dibandingkan formula optimum hasil percobaan

\begin{tabular}{llcccc}
\hline No & Respon & $\begin{array}{c}\text { Percobaan } \\
(\mathbf{n = 3})\end{array}$ & $\begin{array}{c}\text { Prediksi } \\
\text { software } \\
\text { DX7 }\end{array}$ & Nilai $\boldsymbol{p}$ & Kesimpulan \\
\hline 1. & Luas permukaan sebar & $38,99 \pm 3,27$ & 41,89 & 0,264 & Tidak berbeda bermakna \\
2. & Viskositas & $295,56 \pm 1,93$ & 300 & 0,057 & Tidak berbeda bermakna \\
3. & Perubahan viskositas & $3,89 \pm 0,96$ & 3,19 & 0,334 & Tidak berbeda bermakna \\
\hline
\end{tabular}

\section{Uji fisik dan stabilitas formula optimum gel ekstrak kubis ungu}

Uji fisik sediaan gel meliputi organoleptis, luas permukaan sebar, viskositas dan $\mathrm{pH}$. Uji stabilitas sediaan dilakukan selama 4 minggu pada suhu kamar dan uji stabilitas Cycling test. Hasil uji fisik dan stabilitas selama 4 minggu dapat dilihat pada Tabel VI.

\section{Uji aktivitas antioksidan formula optimum gel ekstrak kubis ungu (Brassica oleracea L. var.capitata f.rubra)}

Formula optimum gel ekstrak kubis ungu diuji aktivitas antioksidannya menggunakan metode peredaman radikal bebas DPPH. Perbandingan persentase peredaman radikal DPPH dari ekstrak kubis ungu, formula optimum gel ekstrak kubis ungu dan formula optimum tanpa ekstrak dapat dilihat pada Tabel VI.

Konsentrasi ekstrak kubis ungu yang digunakan pada formula mengacu pada nilai $\mathrm{IC}_{80}$ ekstrak kubis ungu, dimana konsenstrasi ekstrak dalam formula setara dengan $10 x \mathrm{IC}_{80}$ ekstrak murni yaitu $308,97 \mu \mathrm{g} / \mathrm{mL}$ (Senja dkk., 2014) atau 0,3\% per 100 gram formula. Dari tabel di atas, dapat dilihat bahwa perbandingan aktivitas antioksidan ekstrak kubis ungu setelah diformulasi dan aktivitas antioksidan ekstrak murni, didapatkan hasil bahwa formula optimum gel ekstrak kubis ungu memberikan persentase peredaman radikal DPPH sekitar 62,99\%, sedangkan formula optimum gel tanpa ekstrak (basis) memberikan persentase peredaman radikal DPPH 27,48\% yang artinya kestabilan aktivitas antioksidan ekstrak dalam sediaan menurun, karena pada konsentrasi yang sama menghasilkan persen peredaman yang lebih kecil dari $80 \%$ yaitu sekitar $35,51 \%$ (angka ini didapat dari selisih persentase peredaman radikal DPPH dari formula optimum gel ekstrak kubis ungu dengan persen peredaman radikal DPPH dari basis.

Penurunan aktivitas antioksidan ekstrak kubis ungu sesudah diformulasi dalam bentuk sediaan gel kemungkinan disebabkan ketidakstabilan ekstrak dalam formula. Hal ini ditandai dengan terjadinya penurunan $\mathrm{pH}$ sediaan gel pada minggu ke-3 dan ke-4. Disamping itu, penurunan aktivitas antioksidan ekstrak dalam formula kemungkinan terjadi karena adanya efek kompetitif antara ekstrak kubis ungu dengan bahan-bahan dalam formula yang juga memiliki aktivitas peredaman radikal DPPH.

Tabel VI. Hasil uji fisik dan stabilitas formula optimum gel ekstrak kubis ungu selama penyimpanan 4 minggu

\begin{tabular}{|c|c|c|c|c|}
\hline No & $\begin{array}{l}\text { Uji fisik dan } \\
\text { stabilitas }\end{array}$ & Hasil & Nilai $p$ & Keterangan \\
\hline 1. & Organoleptis & $\begin{array}{l}\text { Warna ungu kemerahan } \\
\text { stabil, tektur } \\
\text { lembut,homogen, bau khas }\end{array}$ & - & $\begin{array}{l}\text { Fisik gel stabil selama } 4 \text { minggu } \\
\text { penyimpanan }\end{array}$ \\
\hline 2. & $\begin{array}{l}\text { Uji luas } \\
\text { permukaan } \\
\text { sebar gel }\end{array}$ & $\begin{array}{l}\text { Sediaan stabil selama } 4 \\
\text { minggu penyimpanan. }\end{array}$ & 0,109 & $\begin{array}{l}\text { luas permukaan sebar pada minggu ke- } \\
1 \text { hingga minggu ke- } 4 \text { tidak berbeda } \\
\text { bermakna dengan minggu ke- } 0\end{array}$ \\
\hline 3. & $\begin{array}{l}\text { Uji viskositas } \\
\text { gel }\end{array}$ & $\begin{array}{l}\text { Sediaan stabil selama } 4 \\
\text { minggu penyimpanan }\end{array}$ & 0,090 & $\begin{array}{l}\text { viskositas gel pada minggu ke- } 1 \\
\text { hingga minggu ke- } 4 \text { tidak berbeda } \\
\text { bermakna dengan minggu ke- } 0\end{array}$ \\
\hline 4. & $\mathrm{pH}$ & $\begin{array}{l}\mathrm{pH} \text { gel tidak stabil selama } \\
4 \text { minggu penyimpanan }\end{array}$ & 0,000 & $\begin{array}{l}\mathrm{pH} \text { gel pada minggu ke- } 4 \text { berbeda } \\
\text { bermakna dengan minggu ke- } 0\end{array}$ \\
\hline 5. & Uji Cycling test & Formula optimum stabil & - & Tidak terjadi sineresis gel \\
\hline
\end{tabular}


Tabel VII. Perbandingan persentase peredaman radikal DPPH dari ekstrak kubis ungu, formula optimum gel ekstrak kubis ungu dan formula optimum gel tanpa ekstrak

\begin{tabular}{|c|c|c|c|}
\hline \multirow{2}{*}{$\begin{array}{c}\text { Konsentrasi } \\
\text { sampel } \\
(\mu \mathrm{g} / \mathrm{mL})\end{array}$} & \multicolumn{3}{|c|}{ Persentase peredaman radikal bebas DPPH } \\
\hline & $\begin{array}{c}\text { Ekstrak kubis ungu } \\
(\%)\end{array}$ & $\begin{array}{c}\text { Formula optimum gel } \\
\text { ekstrak kubis ungu } \\
(\%)\end{array}$ & $\begin{array}{c}\text { Formula optimum } \\
\text { gel tanpa ekstrak } \\
(\%) \\
\end{array}$ \\
\hline 20,4 & $16,71 \pm 1,08$ & $3,21 \pm 0,49$ & $1,92 \pm 0,38$ \\
\hline 40,8 & $22,81 \pm 4,48$ & $7,69 \pm 0,80$ & $4,15 \pm 0,32$ \\
\hline 81,6 & $32,31 \pm 2,59$ & $15,56 \pm 0,52$ & $8,16 \pm 0,91$ \\
\hline 163,2 & $49,95 \pm 1,89$ & $33,59 \pm 0,34$ & $12,39 \pm 0,27$ \\
\hline 326,4 & $83,05 \pm 3,23$ & $62,99 \pm 0,74$ & $27,48 \pm 0,52$ \\
\hline
\end{tabular}

\section{KESIMPULAN}

Formula optimum gel ekstrak kubis ungu diperoleh pada proporsi Metolose 3,883\%; propilen glikol 13,5\%; dan Tween 80 sebesar 1,117 \% berdasarkan analisis menggunakan software Design Expert versi 7. Formula optimum yang diperoleh mempunyai respon luas permukaan sebar, viskositas, dan perubahan viskositas yang tidak berbeda bermakna dengan nilai teoritis parameter tersebut $(\mathrm{p}>0,05)$. Formula optimum gel ekstrak kubis ungu memiliki aktivitas antioksidan yang ditandai dengan adanya aktivitas peredaman radikal DPPH dan stabil selama 4 minggu penyimpanan ditinjau dari respon luas permukaan sebar, viskositas, namun tidak stabil ditinjau dari respon derajat keasaman $(\mathrm{pH})$.

\section{DAFTAR PUSTAKA}

Azlim, A.A., Ahmed, J.K., Syed, Z., Musthapa, S., Aisyah, M., dan Kamarul, R., 2010, International Journal of Food Research, 17: 1077-1084.

Bolton, S., 1997, Pharmaceutical Statistics: Practical and clinical aplications, Marcel Dekker, New York, 591-610; 1025-1038.

Djajadisastra, J. dan Dessy, N., 2009, Formulasi gel topikal dari ekstrak nerii folium dalam sediaan anti jerawat, Jurnal Farmasi Indonesia, 4: 210-216.

Garg, A., Aggarwal, S., dan Sigla, A., 2002, Spreading of Semisolid Formulation: An Update. Pharmaceutical Technology, 84-102.

Ghiselli, Nardini, Baldi, dan Scaccini, 1998, Antioxidant activity of different phenolic fractions separated from an italian red wine, Journal of agricultural and food chemistry, 46: 361-367.

Giusti, M.M. dan Wrolstad, R.E., 2001, Characterization and measurement of anthocyanins by uv-visible spectroscopy, dalam: Current Protocols in Food Analytical Chemistry, John Wiley \& Sons, Inc.

Lieberman, H., 1998, Pharmaceutical dosage forms: disperse systems, second edition,(3)2, edition, ed. Informa Healthcare, New York.

Liliana, L., Claudia-Valentina, P., Manuela, S., Andrei, F.D., dan Vasile, D., 2010, Antioxidant activity of Brassica Oleracea L., Allium cepa L. and Beta Vulgaris L. Extracts, Rev. Chim, 61: 911-914.

Mazza, G. dan Miniati, E., 1993, Anthocyanins in Fruits, Vegetables, and Grains, Taylor \& Francis Group.

Neelufar, S., Alekhya, T., dan Sudhakar, K., 2012, Pharmacognostical and phytochemical formulation evaluation of Brassica Oleracea Linn Var. Capitata f. Rubra (The Red Cabbage), Journal of Pharmaceutical Biology, 2: 43-46.

Senja, R.Y., Issusilaningtyas, E., Nugroho, A.K., dan Setyowati, E.P., 2014, Perbandingan metode ekstraksi dan variasi pelarut terhadap rendemen dan aktivitas antioksidan ekstrak kubis ungu (Brassica oleracea var. capitata.f.rubra), Traditional Medicine Journal, 19 (1) : 43-48 .

Voigt, R., 1984, Buku Pelajaran Teknologi Farmasi, dalam: Noerono, S. (Penerjemah), Gadjah Mada University Press, Yogyakarta, 578-580;586. 